\title{
Transbronchial lung cryobiopsy in the diagnosis of interstitial lung disease
}

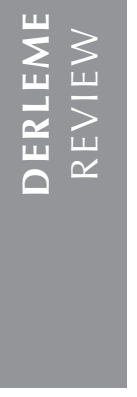

Cite this article as: Keenan I, Backer E, Gibson H, Cho $R$, Dinçer HE. Transbronchial lung cryobiopsy in the diagnosis of interstitial lung disease. Tuberk Toraks 2019;67(4):300-6.

\section{Yazıșma Adresi (Address for Correspondence)}

Dr. H. Erhan DiNÇER

420 Delaware St SE, MMC 276, Minneapolis Minnesota, USA

e-mail: erhan_dincer@yahoo.com

CCopyright 2019 by Tuberculosis and Thorax.

Available on-line at www.tuberktoraks.org.com
${ }^{1}$ Division of Pulmonary, Allergy, Critical Care and Sleep Medicine, Minnesota University, Minnesota, USA

${ }^{1}$ Minesota Üniversitesi, Solunum, Allerji, Kritik Bakım ve Uyku Bölümü, Minnesota, Amerika Birleşik Devletleri

2 Division of Cardiopulmonary Services, Minnesota University, Minnesota, USA

${ }^{2}$ Minesota Üniversitesi, Kardiyopulmoner Bölümü, Minnesota, Amerika Birleşik Devletleri

\begin{abstract}
Transbronchial lung cryobiopsy in the diagnosis of interstitial lung disease

Transbronchial cryoprobe lung biopsy (TBCLB) have recently been introduced as a safe diagnostic tool in the diagnosis of interstitial lung diseases. While we do not enough evidence its role and place as a diagnostic procedure, the technique has been adopted by many centers. In spite of expanding body of literature, there are variations in patient selection and procedural aspect of the procedure. It has been established as a safe procedure if safety measures are practiced. Diagnosis of interstitial lung diseases continuous to be challenging. Surgical lung biopsy considered as gold standard but its morbidity and mortality limit its utilization in every case. Multidisciplinary medical decision is a validated team work effort when approaching patients with interstitial lung disease.
\end{abstract}

Key words: Cryobiopsy; transbronchial; interstitial lung disease

ÖZ

İnterstisyel akciğer hastalığı tanısında transbronşiyal akciğer kriyobiyopsi

Transbronşiyal kriyoprob akciğer biyopsisi (TBCLB), son zamanlarda interstisyel akciğer hastalıklarının tanısında güvenli bir tanı yöntemi olarak gösterilmektedir. Tanıdaki rolü ve yeri hakkında yeterince kanıt bulunmasa da, teknik birçok merkez tarafından kabul edilmiştir. Literatür verilerinin artışına rağmen, hasta seçiminde ve prosedürün uygulanmasında farklılıklar vardır. Gerekli önlemlerin uygulandığı durumlarda, güvenli bir prosedür olarak belirlenmiştir. interstisyel akciğer hastalıklarının tanısındaki zorluklar devam etmektedir. Cerrahi akciğer biyopsisi altın standart olarak kabul edilmektedir, ancak morbidite ve mortalitesi nedeniyle uygulanması kısıtlıdır. Interstisyel akciğer hastaııklarına yaklaşımda, multidisipliner tıbbi karar onaylanmış bir ekip çalışmasıdir.

Anahtar kelimeler: Kriyobiyopsi; transbronşiyal; interstisyel akciğer hastalı̆̆ı 
Transbronchial cryoprobe lung biopsy (TBCLB) is a relatively new technique for sampling lung tissue. This technique relies on the fact that rapidly frozen lung tissue sticks to the tip of the probe allowing larger biopsy specimens with less crush artifact $(1,2)$. The diagnostic yield of transbronchial biopsies with standard forceps is often limited due to smaller size and crash artifact. Therefore, TBCLB offers a potential diagnostic benefit over traditional transbronchial biopsies. In recent years, TBCLB has gained popularity and been used various lung conditions, such as interstitial lung diseases (ILD) or diffuse parenchymal lung disease (DPLD), lung transplantation and lung cancer, to improve diagnostic yield (3-6). Overall, traditional forceps transbronchial biopsies play a minor role in the diagnosis of ILD and it has mainly been used to rule out granulomatous diseases (e.g. sarcoidosis) or infection. Surgical lung biopsy is considered as gold standard for the diagnosis of ILD largely because of large parenchymal tissue allowing evaluation of larger area of preserved architecture and subpleural tissue. Unfortunately, many patients cannot undergo surgical lung biopsies due to underlying advanced lung disease. Moreover, possibility of ILD exacerbation makes clinicians not to choose surgical biopsy as first option. Since the first feasibility study on safety and yield of TBCLB performed by Babiak in 2009, many other studies, mostly retrospective, have been published last several years (5). There are still no widely accepted guidelines on biopsy technique, patient selection, number of biopsies, tissue processing, airway management and anesthesia. This review intends to provide information on diagnostic yield, biopsy techniques and potential complications.

\section{Definition of DPLD and Diagnostic Modalities}

DPLD or ILD is a group of diseases mainly affecting the all three components of the lung; endothelium, interstitium and epithelium. DPLD encompasses over 140 different diseases that eventually lead to increasing cellularity and fibrosis. Prognosis and treatment options vary based on underlying cause, if known. Patients may have a range of outcome from complete remission with or without treatment to progressive and fulminant course. The current recommendation indicates that a multidisciplinary expert team of pulmonologists, radiologists and pathologists should be involved in a consensus clinical diagnosis $(7,8)$. Initial step in diagnosis is taking a thorough history that includes domestic and occupational environmental exposures, connective tissue disease (CTD) or drug toxicity for
DPLD and a family history for familial form of pulmonary fibrosis. If a potential cause is identified, the patient should be evaluated to rule in or rule out other known causes such as CTD, hypersensitivity pneumonitis (HP), pneumoconiosis and iatrogenic causes (e.g. drugs and irradiation). If a specific diagnosis or potential cause is not identified, further work up should be done by serology and blood work for CTD and HP and high-resolution $\mathrm{CT}$ scan of the chest to identify the pattern of involvement. HRCT may reveal a specific pattern leading to a specific diagnosis such as usual interstitial pneumonia (UIP). If the changes suggest DPLD, a multidisciplinary discussion is strongly suggested to determine the need of an invasive procedure. Surgical lung biopsy is considered as gold standard but surgical biopsy in some of the HRCT patterns such as UIP or some familial cases is not necessary. Moreover, surgical biopsy would not be feasible in patients at high risk for respiratory failure, exacerbation of DPLD or prolonged air leak, especially those with hypoxemia at rest, severe pulmonary hypertension or a corrected diffusion capacity of carbon monoxide for hematocrit less than $25 \%$ of predicted (9).

Among invasive procedures, bronchoalveolar lavage is not routinely recommended however can be appropriate when the radiologic differential diagnosis include eosinophilic pneumonia, sarcoidosis or infection. Cell counts (e.g. higher neutrophil proportion in interstitial pulmonary fibrosis, lower proportion of alveolar macrophages in IPF, higher eosinophils in eosinophilic pneumonia and higher CD4/CD8 in IPF and sarcoidosis (10-12).

Transbronchial forceps lung biopsies (TBFLB) has been utilized in attempt to make diagnosis in DPLD however, there are no studies about clinical outcomes in those who underwent TBFLB or not. Current guidelines do not recommend performing TBFLB in patients who are clinically suspected of having IPF with an UIP pattern on HRCT. However, there is no recommendation for or against performing TBFLB in patients with clinically suspected IPF and HRCT findings of probable or intermediate IPF. Nevertheless, unweighted studies indicated that almost three-fourth of cases resulted in adequate sampling and half of those with adequate sampling led to a definitive diagnosis eliminating the need of surgical biopsy (13-15).

Although surgical lung biopsy (SLB) is considered as gold-standard due to the fact that an adequate tissue can be sampled in almost all cases where paucity and 
heterogenicity of parenchymal involvement can be captured as well as subpleural tissue that is important in the diagnosis of UIP. SLB may not be an option in some patients with comorbidities and may result in post-operative complications such as prolonged air leak, bleeding, infection and ILD exacerbation. Risk of procedural mortality, although rare, does exist. Based on most studies, diagnostic yield of SLB was $88 \%-90 \%$. Although there is role in the diagnosis of ILD for SLB, especially when the multidisciplinary discussion is the decision-maker, SLB is not recommended in patients with clinical suspicion of IPF and HRCT pattern of UIP (8,16-19).

Role of TBCLB in the diagnosis of DPLD has been gaining popularity although there is no study compared clinical outcomes for those underwent to biopsy or not. Pooling studies indicated an adequate sampling in majority of cases ( $94 \%$ to $97 \%$ ) in which a definitive diagnosis was achieved in $77 \%-83 \%$. TBCLB is considered to be more invasive than TBFLB and reported have complications of death, bleeding, pneumothorax and prolonged air leak, although the incidence of procedure related death is less than SLB, $0.04 \%-1.3 \%$ vs. $0.8 \%-3.5 \%$, respectively. Based on current guidelines, TBCLB is not recommended in patients with clinically suspected IPF and HRCT pattern of UIP while no specific recommendation was given for those with probable UIP or indeterminate UIP changes on HRCT $(8,20-23)$.

\section{Cryothechnology and its Application in Pulmonary Medicine}

Currently, there are rigid, semi-rigid and flexible cryoprobes with tip diameters of $1.9 \mathrm{~mm}, 2.4 \mathrm{~mm}$ and 5.5 $\mathrm{mm}$ and length of $90 \mathrm{~cm}, 50 \mathrm{~cm}$ and $60 \mathrm{~cm}$ (Spembly Medical Ltd, UK and ERBE, Germany). Cryo equipment has 2 components in addition to the probe; 1 . the console that monitors the cryopressure, probe tip temperature and the length of procedure and 2 . Cryogen such as nitrous oxide, carbon dioxide or liquid nitrogen to free the tip of the probe to $-70^{\circ} \mathrm{C}$, $-89^{\circ} \mathrm{C}$ and $-196^{\circ} \mathrm{C}$, respectively. The technology relies on Joule-Thompson effect in which compressed cryogen gas exits at a high flow, expands rapidly and creates low temperatures to allow tissue adhesion to the tip of the probe (24). Cryotechnology has been used in pulmonary medicine for ablation and diagnostic purposes. Ablation of benign or malignant lesions with cryotherapy relies on the destructive effects that are 2-fold: cellular injury and vascular injury. Ablation effect of cryo technology is beyond the scope of this review therefore we will not review it further.

\section{Cryoprobe Lung Biopsy Techniques}

In 2009, Babiak et al. has introduced cryoprobe lung biopsies as a new tool (5). The biopsy technique has many variations among centers worldwide. Simply, the probe is advanced through the working channel of the bronchoscope into the lung periphery and then the probe is activated with a foot pedal for few seconds causing an ice-ball around the tip of the probe where the lung parenchymal tissue adheres to the ice-ball and probe. At this point, the bronchoscope and the cryo probe attached lung tissue are retracted en-bloc from the airway. Then, the probe is either submerged into a saline or a saline stream instilled on to the frozen probe tip with lung tissue to separate the lung tissue specimen from the probe. Technical variations derive from operators training and logistics within their institution. However, the most important factor plays role in variation is the readiness for dealing with potential complication of the procedure. The potential complications encountered in TBCLB are hemorrhage that maybe excessive leading to respiratory compromise and pneumothorax. It should be remembered that some of the ILD patients have limited respiratory reserve making them vulnerable to complications. Besides dealing with complications, operators may select different techniques when acquiring biopsies that involves selection of probe size $(1.9 \mathrm{~mm}$ vs. $2.4 \mathrm{~mm})$, duration of freezing time, radial EBUS guidance, biopsy location (central or peripheral or pleural based) and number of biopsies in one or multiple lobes (1,3-5,23,25-29).

At present time, there is no single technique that is accepted by the operators. Our group performs cryo probe lung biopsies mostly in the OR while the patient is intubated with an ETT of $8.5 \mathrm{~mm}$ and under general anesthesia. We target the areas of mostly ground-glass opacifications and at least $2 \mathrm{~cm}$ away from the pleural surface. The biopsies ( 3 to 5 biopsies from each lobe) are taken under live fluoroscopy guidance while the patient is on breath hold. The duration of freezing is decided based on the first biopsy size that is usually taken at 4 second mark of freezing time. If the biopsy size is less than $3 \mathrm{~mm}$ we increase the freezing time 2 to 4 seconds. We do not use 2 bronchoscope technique or routine balloon occlusion after each biopsy $(25,30)$. 


\section{Patient Selection and Safety Concerns}

Patient selection is important to alleviate potential procedural complications. There are currently no guidelines about pre-procedural evaluation.

Anticoagulation and antiplatelet agents should be held appropriate time based on their biological halflives. It is generally an accepted practice to keep international normalized ratio (INR) lower than 1.5 and thrombocyte count above 50.000/ $\mathrm{LL}$ (31-33). However, it should be noted that these recommendations are made for transbronchial forceps biopsies or EBUS guided needle biopsies. There are no trials about safety of cryoprobe lung biopsies in patients with coagulopathy or thrombocytopenia. In our practice, we prefer to keep INR less than 1.5 and platelet count above $100.000 / \mu \mathrm{L}$.

Uremia is known to cause platelet dysfunction and increased bleeding risk that is shown to be alleviated with desmopressin (DDAVP) infusion prior to biopsies, risk of bleeding reduced from $45 \%$ to $4 \%$ (3436). Although no evidence, we give DDAVP in those with BUN or greater than $35 \mathrm{mg} / \mathrm{dL}$.

Pulmonary hypertension is a common complication of ILD and defined as a resting mean pulmonary artery pressure equal or greater than $25 \mathrm{mmHg}$. Although right heart catheterization is considered as gold-standard for the diagnosis of pulmonary hypertension, we prefer to screen ILD patients with transthoracic echocardiogram prior to cryoprobe biopsies. Although there is no evidence we do not perform cryoprobe lung biopsies if the mean pulmonary arterial pressure is greater than $35 \mathrm{mmHg}$ (those with moderate pulmonary hypertension). It should be remembered that preprocedural echocardiogram has not universally obtained in most of the studies involving cryoprobe lung biopsies.

Similarly, pulmonary function testing has been used to exclude some of the patients from performing cryoprobe lung biopsies, those with $\mathrm{FEV}_{1}<0.8 \mathrm{~L}$ or $<$ $50 \%$ of predicted, FVC $<50 \%$ predicted and DLCO $<35 \%$ or $50 \%$ of predicted, albeit a recent meta-analysis of 994 cryobiopsy cases did not find a adverse relationship between poor pulmonary functions and complication rates $(28,37,38)$.

Significant hypoxemia $\left(\mathrm{PaO}_{2}\right.$ less than $55 \mathrm{mmHg}$ on room air) is also considered as contraindication in some of the series $(28,37,38)$.

\section{Complications}

Main complications from cryoprobe lung biopsies consists of bleeding, pneumothorax and ILD exacerbation.

In spite of precautions exercised against coagulation, bleeding parameters, medications and pulmonary hypertension in terms of patient selection and pre-procedural patient preparation, bleeding complication has been reported common after cryoprobe biopsies. Unfortunately, there is no accepted scale of bleeding and difficulty to measure bleeding amount, it is hard to compare the incidence of severe bleeding. Most publications utilize a 4-step bleeding as measurement; no bleeding, mild bleeding requiring suctioning only, moderate bleeding requiring endoscopic interventions (e.g. instillation of cold saline, balloon occlusion/tamponade) and severe bleeding leading to respiratory or hemodynamic instability. A meta-analysis of 12 studies and 383 patients, $16.9 \%$ reported to have moderate bleeding with a pooled probability of 0.12 (95\% Cl 0.02-0.25) (40). Although there are no reports of bleeding related mortality in the medical literature, operators should be ready to act on life-threatening bleeding that is a possibility. In our experience, we encounter more bleeding when biopsies are taken from a more central lesions than peripheral lesions that can be explained by the fact that pulmonary artery diameter is larger in adjacent to the central bronchi. Routine usage of bronchial blocker after each biopsy is not standard of care but performed by some centers. However, we strongly recommend having bronchial blockers readily available if it is not used after each biopsy. Although this is anecdotal, we encounter more bleeding in transplant patients likely secondary to nerve denervation leading to poor vasospasm.

The rate of pneumothorax is variably reported in studies. The incidence was reported as $10 \%$ and $9.5 \%$ in 2 recent meta-analyses $(40,41)$. It is believed that UIP histology, biopsies of fibrotic areas and biopsies close pleural surface increase the risk of pneumothorax risk $(37,40)$. Unfortunately, most studies did not provide information about the severity and duration of bronchopleural fistula. As a precautionary measure, we always keep different sizes of chest tubes in the procedure room, examine the chest with ultrasound just after and a chest X-ray one hour after the procedure.

Acute exacerbation of ILD (AE-IPF) is best characterized in IPF but can occur in other fibrotic ILDs. 
Diagnostic criteria for AE-IPF has been updated in 2016 (42). AE-IPF has been described after video-assisted thoracoscopic wedge resection, lobectomy, surgical open lung biopsy and after bronchoalveolar lavage. There are several reports of acute exacerbation of IPF after cryoprobe lung biopsy with incidence up to $2.3 \%$. Although this is not a common occurrence, operators should be aware of this complication and discuss with patients prior to procedure (43-45).

It is also unclear if the centers track their 30-day and 90-day mortality rates following TBCLB. Although meta-analyses report procedural mortality rates of $0.1-0.3 \%$, a retrospective study of 197 patients whom underwent cryoprobe biopsies noted $2 \%$ 30-day and $2.5 \%$ 90-day mortality. All patients died within 30 days of biopsy had poor baseline lung function of less than $35 \%$ predicted DLCO value (46).

\section{Diagnostic Yield of Cryoprobe Lung Biopsy}

While the role of TBCLB in the diagnosis of interstitial lung diseases is evolving, it remains to be an option as a diagnostic tool. Although there are no clear-cut indication criteria about when to perform TBCLB in the diagnosis of ILD, an expert team including interventional pulmonologist should be part of the decision-making process. Currently, cryoprobe lung biopsy is considered when SLB is considered. Some centers favor TBCLB as an initial invasive diagnostic procedure and consider SLB if no definitive diagnosis is established. This is based on the fact that SLB may result in higher morbidity and mortality than cryoprobe biopsies. It is reported that AE-IPF is more common and mortality may occur after SLB $(44,47,48)$.

Diagnostic yield of TBCLB reported $>50.6 \%$ to $100 \%$ in various studies. It should be noted that multidisciplinary discussion (MDD) should weigh in final diagnosis and histologic evaluation should be performed by an experienced lung pathologist (49). In our opinion, many factors influence the final diagnosis; MDD, experience of lung pathologist, size and number of biopsy specimens, presence and amount of alveolar tissue and location of biopsies (subpleural, areas of ground-glass opacifications). TBCLB has been utilized in patients for DPLD but very few studies have published on diagnostic yield of cryoprobe lung biopsy exclusively in patients with ILD. As example, our group published a series of 40 ILD patients in whom TBCLB established a confident histopathologic and MDD consensus diagnosis in $85 \%$ of the cases (30).
A recent study reported a poor concordance between sequential TBCLB and SLB in the diagnosis of diffuse interstitial lung disease. 21 patients initially underwent TBCLB followed by video-assisted thoracoscopy for SLB at the same anatomical location. It was concluded that poor concordance could have been resulted in different management strategy in 11 of 21 $(52 \%)$ of cases (50).

\section{Airway Management and Anesthesia}

There is wide variation in terms of where and how TBCLB is performed. Earlier studies reported airway management with rigid bronchoscopy under general anesthesia in case of major bleeding however safety of the procedure has been established in varies airways (Laryngeal mask anesthesia, endotracheal tube with conventional ventilation or Jet ventilation) and sedation level (general and conscious). Centers usually select the location, anesthesia type and airway modality based on their experiences. Our group has compared diagnostic yield and complication rate of TBCLB in ILD patients in a retrospective study and reported no difference in biopsy quality and diagnostic yield but increased trend of more bleeding requiring cold saline and topical epinephrine instillation (moderate bleeding) in endoscopy unit (30).

\section{Future Directions}

TBCLB is a safe and promising technique in the diagnosis of interstitial lung diseases. Variations in reporting and procedure itself makes difficult to compare published studies. Standardization in patient selection, indications, diagnostic yield, safety precautions and technical aspect will provide more robust information about its utility in diagnosis and other end points such as complication rates. Future comparative studies with surgical lung biopsy and unified data collection are particularly needed.

\section{CONFLICT of INTEREST}

The authors reported no conflict of interest related to this articles.

\section{REFERENCES}

1. Griff S, Ammenwerth W, Schonfeld M, Bauer TT, Mairinger T, Blum TG, et al. Morphometrical analysis of transbronchial cryobiopsies. Diagnostic Pathol 2011;6:53-8.

2. Franke $K J$, Theegarten D, Hann von Weyhern C, Nilius G, Brueckner C, Hetzel J, et al. Prospective controlled animal study on biopsy sampling with new flexible cryoprobes vs forceps: evaluation of biopsy size, histological quality and bleeding risk. Respiratio. 2010;80:127-32. 
3. Yarmus L, Akulian J, Gilbert C, Illei P, Shah P, Merlo C, et al. Cryoprobe transbronchial lung biopsy in patients after lung transplantation. Chest 2013;143:621-6.

4. Fruchter $O$, Fridel L, Rosengarten D, Raviv Y, Rosanov $V$, Kramer MR. Transbronchial cryo-biopsy in lung transplantation patients: first report. Respirology 2013;18:669-73.

5. Babiak A, Hetzel J, Krishna G, Fritz P, Moeller P, Balli T, et al. Transbronchial cryobiopsy: a new tool for lung biopsies. Respiration 2009;78:203-8.

6. Aktas Z, Gunay E, Hoca NT, Yilmaz A, Demirag F, Gunay $S$, et al. Endobronchial cryobiopsy or forceps biopsy for lung cancer diagnosis. Ann Thorac Med 2010;5:242-6.

7. Raghu G, Collard HR, Egan JJ, Martinez FJ, Behr J, Brown $K K$, et al. An official ATS/ERS/JRS/ALAT statement: idiopathic pulmonary fibrosis: evidence based guidelines for diagnosis and management. Am I Respir Crit Care Med 2011;183:788-824.

8. Raghu G, Remy-Jardin M, Myers JL, Richeldi L, Ryerson CJ, Lederer DJ, et al. An official ATS/ERS/IRS/LATS Clinical Practice Guideline. Diagnosis of idiopathic pulmonary fibrosis. Am J Respir Crit Care 2018;198(5):44-68.

9. Hutchinson JP, Fogarty AW, McKeever TM, Hubbard RB. In-hospital mortality after surgical lung biopsy for interstitial lung disease in the United States: 2000 to 2011. Am J Respir Crit Care Med 2016;193:1161-7.

10. Lee W, Chung WS, Hong KS, Huh J. Clinical usefulness of bronchoalveolar lavage cellular analysis and lymphocytes subsets in diffuse interstitial lung diseases. Ann Lab Med 2015;35:220-5.

11. Ohshimo S, Bonella F, Cui A, Beume M, Kohno N, Guzman J, et al. Significance of bronchoalveolar lavage for the diagnosis of idiopathic pulmonary fibrosis. Am J Respir Crit Care Med 2009;179:1043-7.

12. Welker L, Jorres RA, Costabel U, Magnussen H. Predictive value of BAL cell differentials in the diagnosis of interstitial lung diseases. Eur Respir I 2004;24:1000-6.

13. Han $Q, L u o$ Q, Chen X, Xie J, Wu L, Chen R. The evaluation of clinical usefulness of transbronchoscopic lung biopsy in unidentified interstitial lung diseases: a retrospective study. Clin R J 2017; 11:168-75.

14. Sheth JS, Belperio JA, Fishbein MC, Kazerooni EA, Lagstein A, Murray S, et al. Utility of transbronchial vs surgical lung biopsy in the diagnosis of suspected fibrotic interstitial lung disease. Chest 2017;151:389-99.

15. Pourabdollah M, Shamaei M, Karimi S, Karimi M, Kiani A, Jabbari HR. Transbronchial lung biopsy: the pathologist's point of view. Clin Respir J 2016;10(2):211-6.

16. Morris D, Zamvar V. The efficacy of video-assisted thoracoscopic surgery lung biopsies in patients with interstitial lung diseases: a retrospective study of 66 patients. I Cardiothor Surg 2014;9:45-52.

17. Blanco M, Obeso GA, Duran JC, Rivo JE, García-Fontán E, Peña $E$, et al. Surgical lung biopsy for diffuse lung disease: our experiences in the last 15 years. Rev Port Pneumol 2013; 19:59-64.
18. Samejima J, Tajiri $M$, Ogura T, Baba T, Omori T, Tsuboi $M$, et al. Thoracoscopic lung biopsy in 285 patients with diffuse pulmonary disease. Asian Cardiovasc Thorac Ann 2015;23:191-7.

19. Sonobe $M$, Handa $T$, Tanizawa $K$, Sato M, Sato T, Chen F, et al. Video thoracoscopy assisted surgical lung biopsy for interstitial lung diseases. Gen Thorac Cardiovasc Surg 2014;62:376-82.

20. Tomassetti S, Wells AU, Costabel U, Cavazza A, Colby TV, Rossi G, et al. Bronchoscopic lung cryobiopsy increases diagnostic confidence in the multidisciplinary diagnosis of idiopathic pulmonary fibrosis. Am J Respir Crit Care Med 2016;193:745-52.

21. Pajares V, Puzo C, Castillo D, Lerma E, Montero MA, Ramos-Barbón D, et al. Diagnostic yield of transbronchial cryobiopsy in interstitial lung disease: a randomized trial. Respirology 2014;19:900-6.

22. Hagmeyer L, Theegarten D, Treml M, Priegnitz C, Randerath $W$. Validation of transbronchial cryobiopsy in interstitial lung disease interim analysis of a prospective trial and critical review of the literature. Sarcoidosis Vasc Diff Lung Dis 2016;33:2-9.

23. Ussavarungsi K, Kern RM, Roden AC, Ryu JH, Edell ES. Transbronchial cryobiopsy in diffuse parenchymal lung disease: retrospective analysis of 74 patients. Chest 2017;151:400-8

24. Ozerov RP, Vorobyev AA. Physics for chemists. 2007:169250.

25. Sriprasart $T$, Aragaki A, Baughman $R$, WikenheiserBrokamp K, Khanna G, Tanase D, et al. A single US center experience of transbronchial lung cryobiopsy for diagnosing interstitial lung disease with a 2-scope technique. I Bronchol Interv Pulmonol 2017;24:131-5.

26. Hernandez-Gonzalez F, Lucena CM, Ramirez J, Sanchez $M$, Jimenez MJ, Xaubet $A$, et al. Cryobiopsy in the diagnosis of diffuse interstitial lung disease: yield and cost-effectiveness analysis. Arch Bronchoneumol 2015;51:261-7.

27. Berim IG, Saeed Al, Awab A, Highley A, Colanta A, Chaudry F. Radial probe US guided cryobiopsy. I Bronchol Interv Pulmonol 2017;24:170-3.

28. Ravaglia C, Wells AU, Tomasetti S, Dubini A, Cavazza A, Piciucchi $S$, et al. Transbronchial lung cryobiopsy in diffuse parenchymal lung disease: Comparison between biopsy from 1 segment and biopsy from 2 segmentsDiagnostic yield and complications. Respiration 2017;93:285-92.

29. Bango-Alvarez A, Ariza-Prota $M$, Torres-Rivas $H$, Fernandez-Fernandez $L$, Prieto A, Sáanchez $I$, et al. Transbronchial cryobiopsy in interstitial lung disease: experience in 106 cases-how to do it. ERJ Open Res 2017;3(1)

30. Cho R, Zamora F, Gibson H, Dincer HE. Transbronchial lung cryobiopsy in the diagnosis of interstitial lung disease: A retrospective single center experience. I Bronchol Intervent Pulmonol 2019;26:15-21. 
31. Cordasco EM, Jr, Mehta AC, Ahmad M. Bronchoscopically induced bleeding. A summary of nine years' Cleveland clinic experience and review of the literature. Chest 1991;100:1141-7.

32. Gasparini S. Conventional biopsy techniques. In: Ernst A, Herth FJF (eds). Principles and Practice of Interventional Pulmonology. New York: Springer New York, 2013:15163.

33. Papin TA, Lynch JP 3rd, Weg JG. Transbronchial biopsy in the thrombocytopenic patient. Chest 1985;88:549-52.

34. Zavala DC. Pulmonary hemorrhage in fiberoptic transbronchial biopsy. Chest 1967;70:584-8.

35. Cunningham JH, Zavala DC, Corry RJ, Keim LW. Trephine air drill, bronchial brush, and fiberoptic transbronchial lung biopsies in immunosuppressed patients. Am Rev Respir Dis 1977;115:213-20.

36. Jain P, Sandur S, Meli Y, Arroliga AC, Stoller JK, Mehta AC. Role of flexible bronchoscopy in immunocompromised patients with lung infiltrates. Chest 2004;125:71222

37. Casoni GL, Tomasetti S, Cavazza A, Colby TV, Dubini A, Ryu JH, et al. Transbronchial lung cryobiopsy in the diagnosis of fibrotic interstitial lung diseases. PLOS One 2014;9(2):e86716.

38. Pajares V, Puzo C, Castillo D, Lerma E, Montero MA, Ramos-Barbon D, et al. Diagnostic yield of transbronchial cryobiopsy in interstitial lung disease: a randomized trial: Transbronchial cryobiopsy. Respirology 2014;19:900-6.

39. Ernst $A$, Eberhardt R, Wahidi M, Becker HD, Herth FJ. Effect of routine clopidogrel use on bleeding complication after transbronchial biopsy in humans. Chest 2006; 129:734-7.

40. Ravaglia C, Bonifazi M, Wells AU, omassetti S, Gurioli C, Piciucchi S, et al. Safety and diagnostic yield of transbronchial lung cryobiopsy in diffuse parenchymal lung disease: a comparative study versus video assisted thoracoscopic lung biopsy and a systemic review of the literature. Respiration 2016;91:215-27.

41. Iftikhar IH, Alghothani L, Sardi A, Berkowitz D, Musani Al. Transbronchial lung cryobiopsy and video-assisted thoracoscopic lung biopsy in the diagnosis of diffuse parenchymal lung disease: a meta-analysis of diagnostic test accuracy. Ann Am Thorac Soc 2017; 14:1197-211.
42. Collard HR, Ryerson TJ, Corte TJ, Jenkins G, Kondoh Y, Lederer DJ, et al. Acute exacerbation of idiopathic pulmonary fibrosis an international working group report. Am I Respir Crit Care 2016;194(3):265-75.

43. Amundson $W H$, Racila $E$, Allen $T$, Dincer HE, Tomic $R$, Bhargava $M$, et al. Acute exacerbation of interstitial lung disease after procedures. Respir Med 2019;150:30-7.

44. Tomic R, Cortes H, Kim H, Joo Kim H, Amin K, Dincer HE. Acute exacerbation of interstitial lung disease after cryoprobe lung biopsy. I Bronchol Interv Pulmonol 2017;24:319-22.

45. Dhooria S, Mehta A, Srinivasan K, et al. A multi-center study on the safety and efficacy of different methods for obtaining transbronchial lung cryobiopsy in diffuse lung diseases. Clin Res J 2017.

46. Pannu J, Roller LJ, Maldonado F, Lentz RJ, Chen H, Rickman OB. Transbronchial cryobiopsy for diffuse parenchymal lung disease: 30- and 90-day mortality. Eur Respir J 2019;54(4).

47. Hutchinson JP, Fogarty AW, MCKeever TM, Hubbard RB. In-hospital mortality after surgical lung biopsy for interstitial lung disease in the United States. 2000-2011. Am J Respir Crit Care 2016;193:1161-7.

48. Utz JP, Ryu JH, Douglas WW, Hartman TE, Tazelaar HD, Myers $L$, et al. High short-term mortality following lung biopsy for usual interstitial pneumonia. Eur / Respir 2001; 17:175-9.

49. Hetzel I, Maldonado F, Ravaglia C, Wells AU, Colby TV, Tomassetti $S$, et al. Transbronchial cryobiopsies for the diagnosis of diffuse parenchymal lung diseases: Expert statement from the cryobiopsy working group on safety and utility and a call for standardization of the procedure. Respiration 2018;95:188-200.

50. Romagloni M, Colby TV, Berthet JP, Gamez AS, Mallet JP, Serre I, et al. Poor concordance between sequential transbronchial lung cryobiopsy and surgical lung biopsy in the diagnosis of diffuse interstitial lung disease. Am J Respir Crit Care 2019;199(10):1249-56. 